\title{
Preliminary study on vertical distribution of microorganisms in the Bannock Basin waters (Eastern Mediterranean Sea)
}

\author{
R. La Ferla, E. Crisafi \\ Istituto Sperimentale Talassografico CNR, Messina, Italy
}

\begin{abstract}
Preliminary data are presented on microbial distribution in the Bannock Basin, a hypersaline and anoxic depression in the lower $3300 \mathrm{~m}$ of the water column. Epifluorescence microscopy was suitable for a first approach to enumeration of the microbial mass in water samples from this peculiar marine environment. Progressive increase in total microbial numbers occurs in the anoxic layer, with the highest value at $3331 \mathrm{~m}$. Autofluorescing microorganisms are also present.
\end{abstract}

The Bannock Basin is an anoxic deep (ca $3790 \mathrm{~m}$ ) basin, with gypsum precipitation and cold brines, situated in the Ionian Basin close to the Sirte Abyssal Plane (34 $18^{\prime}$ lat. $N, 20^{\circ} 00^{\prime}$ long. E) in the Eastern Mediterranean Sea. The oxic-anoxic interface lies at ca $3300 \mathrm{~m}$, at which depth oxygen is depleted and salinity and density are unusually high. Stratification prevents vertical mixing and results in an increase of hydrogen sulphide, probably due to bacterial activites. The Bannock Basin brine is the most concentrated of any other anoxic hypersaline basin known so far: Red Sea, Orca Basin and Tyro Basin. Moreover, it is the only one where gypsum precipitation is not due to hydrothermal activity.

Previous research on water samples from the Bannock Basin and the overlying water reveals 4 layers with different characteristics. We report depths as pressure values (dbar), just like the multiparameter probe measured, because the conversion equation to metres cannot be correctly applied in exceptionally high salinities and densities. In the first layer (from 0 to 3300 dbar), water shows the typical features of the Eastern Mediterranean Sea; in the second one (from 3300 to $3327 \mathrm{dbar}$ ), oxygen values fall instantaneously to zero, whereas salinity, nitrates, nitrites and phosphates increase and, in the deeper part of the layer, hydrogen sulphide begins to occur; the third layer (from 3327 to 3370 dbar) is characterized by a sharp increase in salinity (to $300 \%$ ), density and hydrogen sulphide, as well as absence of oxygen; it represents the first brine layer; the last layer (from 3370 dbar to the bottom) represents the brine body with chemical parameters similar to the foregoing layer with a maximum of $325.3 \%$ (Bregant et al. 1990).

During a 1987 cruise, preliminary investigations revealed a normal distribution of culturable bacteria in the oxygenated layer of the Bannock Basin, but sporadic colonies grew from the anoxic and hypersaline samples (De Domenico \& De Domenico 1989). In such extreme environments microbial populations should be highly specialized and differentiated; hence it is very difficult to enumerate them accurately by cultural methods.

During a cruise in 1988, in order to estimate the total microbial number in the Bannock Basin (sub-basin Libeccio) and in the overlying water, a quantitative investigation applying a microscopic method was carried out. Microbial cells were enumerated using the ASTM method (1985), modified according to La Ferla et al. (1990). The number of autofluorescent microbial cells (photopicoplankton) was determined. Such microorganisms are part of the total microbial population and participate in the primary production of the sea (Fogg 1986, Li \& Platt 1987). Such cells were detected according to El Hag \& Fogg (1986).

The saltiest samples caused methodological problems in cell counting, as already mentioned by Harvey (1987) who studied meromictic saline lakes. In order to avoid these problems, several rinses on the filter or dilutions of the samples were carried out.

Our results demonstrate the presence of an abundant microbial flora in Bannock Basin. The total microbial counts in the whole water column vary from $4.1 \times 10^{5}$ to $1.1 \times 10^{6}$ cells $\mathrm{ml}^{-1}$, with an average of $7.2 \times 10^{5}$ cells $\mathrm{ml}^{-1}$ (Fig. 1). Autofluorescent microorganism counts range between $1.8 \times 10^{2}$ and $1.9 \times 10^{4}$ cells $\mathrm{ml}^{-1}$, with 

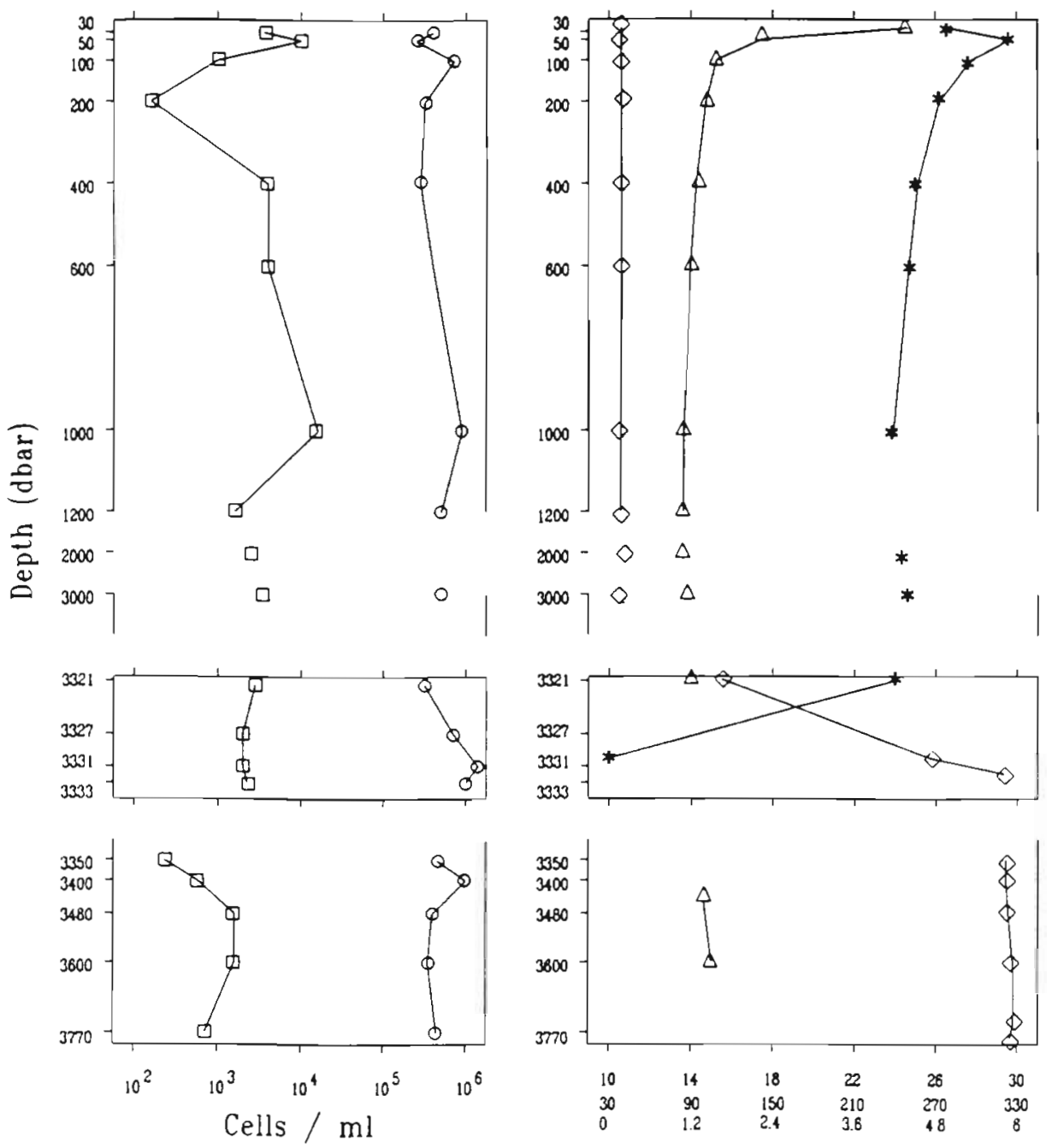

A

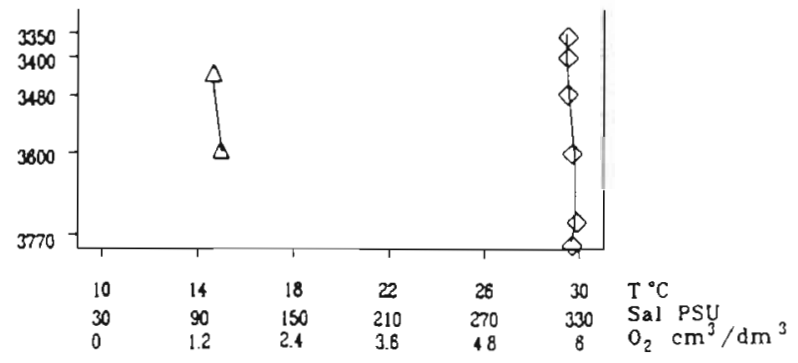

Fig. 1. Distribution of microbial numbers and hydrological characteristics at different water depths. A: Enlargement of the layer between 3321 and 3337 dbar. Physical and chemical data were kindly provided by Dr Bregant. (o) Total microbial cells; $(\square)$ autofluorescent microbial cells; $(\diamond)$ salinity; $(*)$ oxygen; $(\Delta)$ temperature

an average of $4.2 \times 10^{3}$ cells $\mathrm{ml}^{-1}$ in the whole water column. Such organisms constitute approximately $0.6 \%$ of the total microbial population.

Regarding the microbial distributions in the water column, it is usual for microorganisms to decrease with increasing depth. However, microbial distributions are also related to the organic matter concentration and to hydrological phenomena such as the interface of water masses with different densities. Thus, the higher counts at $100 \mathrm{dbar}\left(8.5 \times 10^{5}\right.$ cells $\left.\mathrm{ml}^{-1}\right)$ correspond with the DOC increase found by Henneke \& de Lange (1989) during the same cruise. The increase in microbial abundance at $1000 \mathrm{dbar}\left(9.5 \times 10^{5} \mathrm{cells} \mathrm{m}^{-1}\right)$ is related to the different density of the deepest Mediterranean Sea water compared to the middle Levantine one (De Domenico et al. 1990).

In the anoxic layer there is a progressive increase in the total number of microorganisms, with the highest value at $3331 \mathrm{dbar}$, i. e. higher than in the superficial layer The presence of brines corroborates this result and agrees with POC distribution at the same depth (Henneke \& de Lange 1989). These authors hypothesize that the density discontinuity between oxic and anoxic waters allows the organic matter to accumulate at the interface. The importance of oceanic discontinuities (e.g. thermoclines, pycnoclines, ocean fronts, water mass interfaces) for production and maintenance of subsurface zones of elevated microbial biomass and activity is well known. Thus interfaces support the development of heterotrophic and, in this case, chemoautotrophic populations. Finally, the slight increase in values in the deepest sample is a normal phenomenon near the bottom in aquatic environments. 
The number of phototrophic microorganisms is below normal values for oceanic sea waters (about $10^{4}$ cells $\mathrm{ml}^{-1}$ ). The total microbial counts in relation to the autofluorescent cells reveal opposite trends from the surface to 400 dbar. According to Fogg (1986), the phototrophic picoplankton and the heterotrophic bacteria constitute a basic and ubiquitous planktonic community, and densities of both are determined by the dynamic balance between their growth in a closed selfsustaining cycle.

The presence of autofluorescent cells at great depth is of particular ecological interest. The occurrence of these organisms with photosynthetic pigments below the photic zone is surprising. We suppose that these organisms are cyanobacteria, because they contain phycoerithrin as an intracellular nitrogen reserve to be used in case of need ( $\mathrm{Li} \&$ Platt 1987). The specific set of filters that we used permits counting of unicellular phycoerythrin-containing cyanobacteria, which can unambiguously be distinguished from other phytoplankton or bacteria by their characteristic orange autofluorescence, as asserted by Waterbury et al. (1979) and by El Hag \& Fogg (1986). The ecological significance of such a pigment may not be limited to its functional photosynthetic role; its presence implies the existence of quiescent and conservative forms, sinking from euphotic layers.

Further sampling is needed to confirm the preliminary data reported here.

Acknowledgements. The authors thank Dr Davide Bregant (Istituto Sperimentale Talassografico C.N.R. Trieste) and Professor Emilio De Domenico (Università di Cagliari) who fur-

This article was presented by A. Bianchi, Marseille, France nished the samples and stimulated our research, and Prof. Armand Bianchi (C.N.R.S. Marsiglia) for critically reviewing our manuscript.

\section{LITERATURE CITED}

ASTM (1985). American Society for Testing and Materials. Standard methods for enumeration of aquatic bacteria by epifluorescence microscopy counting procedure. Designation D4455/85, 11 02, Philadelphia, p. 632-634

Bregant, D., Catalano, G., Civitarese, G., Luchetta, A. (1990). Some chemical characteristics of the brines in Bannock and Tyro Basins: salinity, sulphur compounds, $\mathrm{Ca}^{2+}, \mathrm{F}^{-}$. $\mathrm{pH}, \mathrm{A}_{4}, \mathrm{PO}_{4}^{3-}, \mathrm{SiO}_{2}, \mathrm{NH}_{3}$. Mar. Chem. 31: 35-62

De Domenico, M., De Domenico, E. (1989). Bannock Basin: first approach to water microbiology. Ricerca scient. 72 (Suppl.): 100-102

De Domenico, M., Genovese, L., De Domenico, E. (1990). Valutazione delle comunita microbiche in acque pelagiche del mar Jonio. Oebalia 16 (Suppl. 1): 497-506

El Hag, A. G. D., Fogg, G. E. (1986). The distribution of coccoid blue-green algae (Cyanobacteria) in the Menai Straits and Irish Sea. Br. phycol. J. 21 45-54

Fogg, G. E. (1986). Picoplankton. Proceedings IV ISME, p. 96-100

Harvey, R. W. (1987). A fluorochrome-staining technique for counting bacteria in saline, organically enriched, alkaline lakes. Limnol. Oceanogr. 32 (4): 993-995

Henneke, E., de Lange, G. J. (1989). The distribution of DOC and POC in Tyro and Bannock Basins. Ricerca scient. (Suppl.) 72: 95-96

La Ferla, R., Crisafi, E., Genovese, L. (1990). Primi dati sulla distribuzione del batterioplancton nell'area lagunare di Oliveri-Tindari. Oebalia 16 (Suppl. 1): 457-466

Li, N. K. N., Platt T. (1987). Photosynthetic picoplankton in the ocean. Sci. Prog. 71: 117-132

Waterbury, J. B., Watson, S. W., Guillard, R. R., Brand, I. E. (1979). Widespread occurrence of a unicellular, marine, planktonic, cyanobacterium. Nature, Lond. 277: 293-294

Manuscript first received: January 29, 1991

Revised version accepted: June 4, 1991 